\title{
IAVCEI: from small beginnings to a vibrant international association
}

\author{
Raymond A. F. Cas ${ }^{1,2}$ \\ ${ }^{1}$ School of Earth, Atmosphere and Environment, Monash University, Clayton, Victoria, 3800, Australia \\ ${ }^{2}$ School of Physical Sciences, University of Tasmania, Hobart, Tasmania, 7005, Australia
}

Correspondence: Raymond A. F. Cas (ray.cas@monash.edu)

Received: 15 November 2018 - Revised: 5 February 2019 - Accepted: 5 February 2019 - Published: 16 April 2019

\begin{abstract}
The International Association for Volcanology and Chemistry of the Earth's Interior (IAVCEI) was formed following the end of World War I at the inaugural general assembly (GA) of the International Research Council in Brussels in 1919, where the International Union of Geodesy and Geophysics (IUGG) was constituted. IAVCEI was then known as the Section for Volcanology (SV) and was one of six scientific disciplines that made up IUGG. The first president of IAVCEI (or SV) was Annibale Riccò (Italy), its first two vice presidents were Alfred Lacroix (France) and Henry Washington (USA), and the first secretary-general (SG) was Alessandro Malladra (Italy). A secretariat office for SV was established in Naples, Italy, following the first IUGG and SV General Assembly in 1922, in Rome, Italy. At that meeting SV established its own scientific journal called Bulletin volcanologique, the first edition of which was published in 1924 with Alessandro Malladra as the editor. SV officially became the International Association for Volcanology (IAV) in 1933 at the 5th IUGG General Assembly in Lisbon, Portugal. At the 14th IUGG General Assembly in Zurich, Switzerland, in 1967, IAV was renamed IAVCEI in recognition of the importance of geochemistry and geochronology in understanding volcanic processes. Bulletin volcanologique was renamed the Bulletin of Volcanology in 1986, at the time that its editorial board was restructured to be more representative of the international community. IAVCEI became a fully democratic association in 1995 with the introduction of individual membership, which entitled members to nominate, be nominated and vote in the election of the IAVCEI Executive Committee. Although the IUGG By-Laws allowed scientists only from the union's member countries to hold various positions within IUGG, in 2015, the IUGG Council removed this restriction, and now a scientist who is a member of IAVCEI from any country can hold any position in IAVCEI, except the position of the president.
\end{abstract}

\section{Introduction}

At the end of World War I in 1918, representatives of national academies from the allied nations held meetings in London and Paris to establish the International Research Council (IRC). At the first IRC General Assembly in Brussels in 1919, it was decided that the International Astronomical Union and the International Union of Geodesy and Geophysics would be established (IUGG; Lyons, 1919; IsmailZadeh, 2016). IUGG was thus constituted in July 1919 in Brussels, and it brought together several geoscientific disciplines that had existed as independent scientific organisations prior to World War I - geodesy, terrestrial magnetism and electricity, meteorology, physical oceanography, and seismology (Ismail-Zadeh, 2016). Volcanology was also included, even though it does not appear to have had a formal international organisational presence prior to this. These scientific disciplines of IUGG were initially called "Sections" (of IUGG). The International Association for Volcanology and Chemistry of the Earth's Interior (IAVCEI) was therefore initially called the Section of Volcanology (SV) of IUGG when it became constitutionally legitimate in 1919 (Gasparini and Johnson, 1995). The first general assembly of IUGG, and of SV (IAVCEI), was held in Rome, Italy, in 1922. 

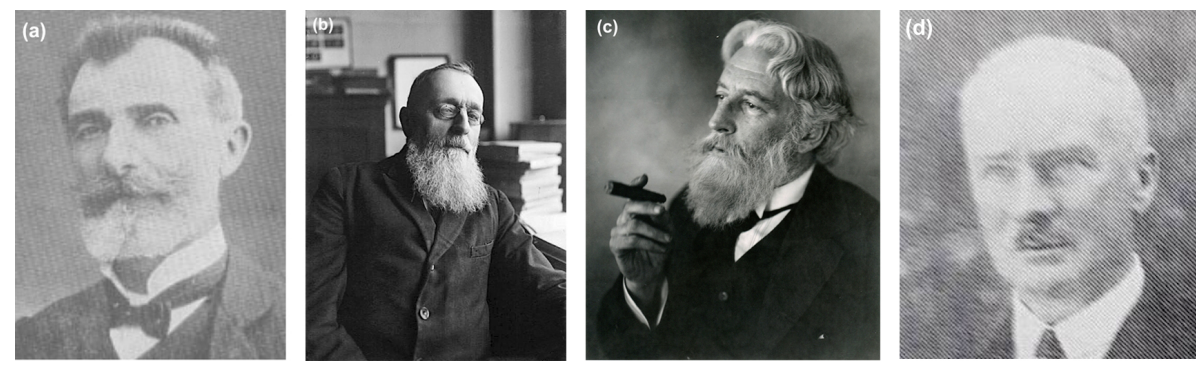

Figure 1. Key personnel responsible for the formation of IAVCEI. (a) Annibale Riccò, first president of IAVCEI (source: Osservatorio Astronomico di Palermo website - http://www.astropa.inaf.it/annibale-ricco/, last access: 11 July 2018). (b) Alfred Lacroix, the first co-vice president and second president (source: Wikipedia - https://en.wikipedia.org/wiki/Alfred_Lacroix, last access: 11 July 2018). (c) Henry S. Washington, first co-vice president (source: Milton, 1991, American Academy of Science). (d) Alessandro Malladra, first secretary-general, subsequent president and first editor of Bulletin volcanologique (source: http://www.minerbook.it/, last access: 11 July 2018). Parts (a), (b) and (d) are public domain; part (c) permission was granted by US National Academy of Science.

This article traces the evolution of IAVCEI, its governance and activities for its first 100 years as an international learned society or association, from 1919 to 2019.

\section{The evolution of IAVCEI}

\subsection{The movers and shakers behind IAVCEl's formation in 1919}

The movers and shakers who are credited with establishing the Section for Volcanology in IUGG in 1919 are Annibale Riccò (Italy), Alfred Lacroix (France), Henry S. Washington (USA) and Alessandro Malladra (Italy; Fig. 1; Gasparini and Johnson, 1995). Annibale Riccò (Fig. 1a) was a celebrated Italian astronomer, with interests in other natural sciences, including seismology. He served as an astronomer at the universities of Modena; Naples, Palermo, and at the time of appointment, Catania (all in Italy). Alfred Lacroix (Fig. 1b) was a French volcanologist at the Museum of Natural History in Paris and was most famous for his account of the 1902 eruption of Mount Pelée, which killed $\sim 30000$ people in the coastal town of Saint-Pierre, Martinique, and for defining the concept of nuées ardentes ("glowing clouds" or pyroclastic flows). Henry S. Washington (Fig. 1c) was a wellknown American petrologist and geochemist at the Carnegie Institute in Washington DC, who was integral to introducing the normative mineralogy composition concept. Alessandro Malladra (Fig. 1d) was an Italian volcanologist from the Vesuvius Observatory in Naples.

At that inaugural general assembly of the International Research Council in Brussels, Belgium, in 1919, where IUGG was formed as a union of six disciplinary sections, Annibale Riccò was elected as the first president of the Section for Volcanology (SV), Alfred Lacroix and Henry Washington were elected vice presidents, and Alessandro Malladra was elected as secretary-general (SG). The process is not clear, but presumably it was by the consensus of the shakers and movers involved in setting up SV. Sadly, Riccò died after only 2 months into his term as president. Lacroix took over the duties of president de facto but was not formally installed as president until the first IUGG General Assembly in Rome, Italy, in 1922, at which Washington was elected vice president and Malladra was confirmed as secretary-general.

\subsection{How IAVCEI evolved from 1919 onwards}

At the 1922 IUGG General Assembly, SV decided to establish a bureau or office for the section in Naples, Italy, where Malladra was based. In his capacity as secretarygeneral, Malladra also oversaw the introduction of Bulletin volcanologique, the precursor to the Bulletin of Volcanology (BV). The title in French accords with French being one of the two official languages of IUGG. The first volume of $B V$ was published in 1924, with Alessandro Malladra as the editor. He continued as editor until 1936, in addition to being secretary-general.

IAVCEI's first scientific conference or meeting, where scientists from several countries presented their research, volcanological issues were discussed and reports on significant recent volcanic eruptions were presented, was part of the first IUGG General Assembly held in Rome in 1922. The number of participants was not recorded, but representatives from Belgium, Canada, France, the United Kingdom, Italy, Japan, Norway, Portugal, Spain, Sweden, Switzerland and the USA participated in IAVCEI's first general assembly (Gasparini and Johnson, 1995). At the 4th IUGG General Assembly in Stockholm, Sweden, it was decided to rename the IUGG Sections as Associations (Gasparini and Johnson, 1995), which was implemented at the 5th IUGG General Assembly in Lisbon, Portugal, in 1933 (Ismail-Zadeh, 2016). SV thus became the International Association for Volcanology (IAV) in 1933. At the 14th IUGG General Assembly in Zurich, Switzerland, in 1967, IAV was renamed IAVCEI in recognition of the importance of geochemistry and geochronology in understanding volcanic processes (Gasparini and Johnson, 1995). 
Since 1922, IAVCEI has held regular major scientific meetings about every 2 years. The meetings held in conjunction with IUGG General Assemblies were called IAVCEI General Assemblies (GAs; where business and scientific meetings were held); these were held every 2-3 years, and since 1963, they have been held every 4 years, except during World War II (see http://www.iugg.org/assemblies/, last access: 11 July 2018, for a list of dates and locations). In between the GAs, IAVCEI has held its own major conferences, called IAVCEI Scientific Assemblies (SAs), although the one held in 1977 was a joint meeting with the International Association for Seismology and Physics of the Earth's Interior (IASPEI; see Supplement). Attendances have progressively increased from $\sim 500$ in 1977 at the Durham, UK, SA to $>1000$ at the 2013 Kagoshima, Japan, SA and 1400 at the 2017 Portland, USA, SA. There was, however, a decrease in numbers immediately after the global financial crisis of 2008. Over the last 20 years, new conferences, initiated by the Commission for Cities and Volcanoes and called "Cities on Volcanoes" (CoV) conferences, have become very popular, attracting over 600 people at recent conferences. These are also held about every 2 years (see Supplement). All conferences are held in different locations and countries, and the venue is based on interested countries competing to host each conference.

\section{Governance}

\subsection{Office bearers and committee}

IAVCEI is managed by an elected committee called the IAVCEI Executive Committee. The principal office bearers of IAVCEI have been its presidents and secretaries-general (the latter is also the treasurer). In addition, a committee, variously consisting of one or, more recently, two vice presidents and four other members, provides advice and help in the decision-making process. Together with the president, secretary-general and immediate past president ex officio, they constitute the executive committee of IAVCEI. The current committee is listed on the IAVCEI website (https: //www.iavceivolcano.org, last access: 11 July 2018), and the list of past IAVCEI office bearers is summarised in the Supplement. The lengths of committee terms have varied in the past, but since 1963 the terms for all committee members have been 4 years, except for the secretary-general, whose term is 8 years to provide continuity. Committee members can be re-elected after their first 4-year term for only one further 4-year term, but they may nominate for the presidency or secretary-general position thereafter. All committee positions are voluntary, and the IAVCEI community is indebted to those who have given their time to serve as committee members.

\subsection{Election of IAVCEI executive committees by IAVCEI members and introduction of individual membership}

The IAVCEI Executive Committee is now elected by IAVCEI members in the months before each IAVCEI general assembly, after an open call for nominations from IAVCEI members. The election is conducted by an election oversight committee appointed by the president, and is usually chaired by the past president, two terms earlier. The editor of the Bulletin of Volcanology is appointed by the executive committee after an open call for expressions of interest.

Prior to 1995, candidates for the IAVCEI committees were identified following enquiries by the outgoing executive committee about suitable candidates who were representative of the IAVCEI community worldwide. In 1995, under the presidency of Grant Heiken, the IAVCEI Executive Committee introduced personal membership in order to develop a stronger sense of community; to help raise funds for the many meetings and workshops that IAVCEI organised every year, which could not be adequately funded by annual budget allocations from IUGG; and to provide a sounder financial base for publication of the Bulletin of Volcanology. As a result, IAVCEI members became eligible to nominate, be nominated and vote for candidates for the IAVCEI Executive Committee. Officially, IUGG did not support individual membership or membership fees in the IUGG associations, and there had been many tense exchanges between IAVCEI and the IUGG executive before and after the 1995 declaration on individual membership. IUGG Statutes stated that the executive committees of the associations could only be voted on by the official national correspondents to each association who could only come from member countries of IUGG with membership dues paid. The problems with this scheme were many, including the disenfranchisement of many volcanologists who were very active in IAVCEI but came from countries that were not financial members of IUGG. This was clearly unfair in an increasingly modern, inclusive and democratic world. So from 1995 onwards, IAVCEI executive committees were elected by all members of IAVCEI irrespective of their countries of residence and contrary to the IUGG Statutes.

Unfortunately, this meant that while IUGG adhered to its statutes, IAVCEI executive committees could be declared illegitimate by IUGG if it chose. To overcome this constitutional impasse, the IAVCEI Executive Committee of 20112015 undertook a hard, and again at times tense, campaign to convince IUGG and its other member associations of the merits of allowing associations to introduce individual membership, the charging of membership fees and democratisation of the elections of association executive committees, if they so wished. This involved allowing all registered members, irrespective of country of residence, to be eligible to nominate candidates, to be nominated as a candidate and to participate in the election of the committees. At one stage, IAVCEI considered seceding from IUGG if these ba- 
sic democratic principles were not agreed to. The proposal was overwhelmingly supported by the IUGG Council at its meeting at the IUGG General Assembly in Prague, given that two other associations also already had a form of personal membership in place, demonstrating that attitudes on personal membership in IUGG were changing. In addition, IAVCEI demonstrated that it was by far the most active association in IUGG in terms of conferences, workshops and short courses, which it could only do using funding generated by personal membership fees.

The only position now on the IAVCEI Executive Committee that must be filled by a representative from an IUGG financial member country is the president. This was a concession to IUGG, since the finances of IUGG, and thus the associations, which all receive an annual monetary allocation from IUGG, are all derived from the subscriptions paid to IUGG by member countries and from the budgets of the national academies of science of those countries. The perceived benefits of being a country member of IUGG is the right to contribute to the formulation of scientific policy at an international level through IUGG and then through the International Council for Science (ICSU), now called the International Science Council (ISC).

From 1995 to 2011, the election of the IAVCEI Executive Committee was conducted by hard-copy ballot papers and snail mail. The elections of the 2011-2015 and 2015-2019 IAVCEI committees were successfully conducted online.

\subsection{Statutes}

Gasparini and Johnson (1995) note that statutes (or constitution) for the International Association for Volcanology (IAV) were adopted at the general assembly in Helsinki, Finland, in 1960. It is assumed that prior to this IAV Statutes mirrored those of IUGG, although information on this is invited from readers. Following these 1960 statutes, IAV's scientific activities were managed through four sections, namely active volcanoes, volcano-physics, physics and chemistry of magmas, and paleovolcanology, and the presidents of these were members of the IAV Bureau. At the IUGG General Assembly in Zurich in 1967, IAV became IAVCEI, and more flexible working groups on topical research themes were introduced to replace the more rigid sections. There was then a further revision of IAVCEI's statutes at the 1979 IUGG General Assembly, in which "Working Groups were replaced by Commissions and Task Groups, the former having the aim of promoting and co-ordinating scientific activity on large themes on a permanent basis, the latter being focussed on temporary problems or on frontier areas of volcanological research" (Gasparini and Johnson, 1995).

In 1995 at the IAVCEI General Assembly in Boulder, USA, and again in revised statutes passed at the 2011 IAVCEI General Assembly in Melbourne, Australia, the concept of individual scientists becoming "affiliates" of IAVCEI and making "donations" were intro- duced. At the 2015 IAVCEI General Assembly in Prague, Czech Republic, the concept of membership for scientists from all countries, involving fee payment, was included in revised statutes, which are available on the IAVCEI website: https://www.iavceivolcano.org/about-iavcei/ statute-and-by-laws.html (last access: 11 July 2018).

\section{IAVCEI major conferences, locations and years}

IAVCEI has organised major conferences since 1922, interrupted only during World War II, and now has three regular major conferences.

\subsection{General assemblies}

Since 1922, IAVCEI's general assemblies have been held in conjunction with the IUGG general assemblies. General assemblies serve as both scientific research meetings where new research is presented in a series of symposia and workshops and as business meetings where new committees are inducted and awards for research excellence are presented and celebrated. GAs also allow for joint interdisciplinary research symposia with other IUGG associations. The timing, locations and known numbers of delegates from all IUGG associations attending the IAVCEI-IUGG general assemblies can be found in the Supplement.

\subsection{Scientific assemblies}

IAVCEI's scientific assembly conferences, which occur between the general assemblies, seem to have only commenced in 1977 and have been held roughly every 4 years since then (see the Supplement for the timing, locations and known numbers of delegates). At scientific assemblies IAVCEI organises an in-house stand-alone scientific conference with emphasis on research, including a celebration of research achievements through presentation of research awards. In addition, there have been some "irregular" meetings, called Volcanological Congresses, which are also listed with scientific assemblies.

\subsection{Cities on Volcanoes conferences}

IAVCEI's Commission on Cities and Volcanoes has now organised $10 \mathrm{CoV}$ conferences. These tend to cater more to consideration of volcanic hazard, eruption monitoring and civil response issues than the general and scientific assemblies (see the Supplement for the timing, and locations of $\mathrm{CoV}$ conferences). In addition, IAVCEI research commissions have organised many other conferences, workshops and field workshops all over the world, making IAVCEI one of the most active associations in IUGG. 


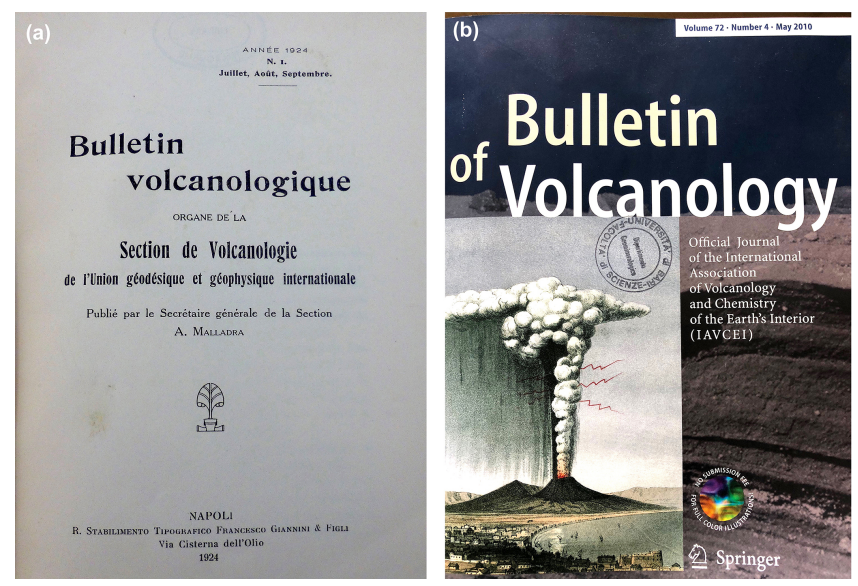

Figure 2. Two versions of the cover of $B V$. (a) Volume 1, no. 1, from July-September 1924. (b) Cover design from last hard-copy version of $B V$, this issue being Volume 72, no. 4, 2010.

\section{Bulletin volcanologique and Bulletin of Volcanology}

\subsection{Origin and history}

Since very early in its history, IAVCEI has produced its own journal, called Bulletin volcanologique, from 1924 to 1984, renamed the Bulletin of Volcanology from 1986 on. The first volumes were released spasmodically, and in a confusing manner, in two series. Volume I, series I, has eight issues and/or parts, six of which were released over 2 years in 19241925 (Fig. 2), and the last, issue 8, was released in 1931. However, there is some discrepancy in published dates on the Bulletin of Volcanology website of Springer, which does not include original journal covers. The break from 1931 to 1937 presumably represents the impact of the Great Depression of the late 1920s and early 1930s, with series II beginning in 1937. Volumes 3 and 4 (of series II) were published in 1938, volume 5 in 1939, and volumes 6 and 7 in 1940, which is when World War II was well under way (continuing until 1945); during this period no volumes of $B V$ were published. The first post-World War II volume appeared in 1949 (Volume 8), and $B V$ has been published more or less continuously since. No volume numbers were, however, skipped; their publication was just delayed. The covers of post-World War II volumes are labelled Series II, suggesting that after the initial volume I (series I, 1924-1936), the clock was reset in 1937 with the commencement of series II, beginning with another volume 1 .

The source of funding to support publication of $B V$ in the early years is unclear, but in the 1950s to early 1960s funding was provided by UNESCO, and then during the 1960s and 1970s, it was provided by the National Research Council of Italy, as acknowledged on the covers of $B V$. From the mid-1980s, after publication was handed over to Springer in
Germany, funding was provided by IAVCEI and also sourced from journal subscriptions, which continues to the present.

For over 40 years, from 1924 to 1966, the secretarygeneral was also the editor of $B V$. Up until 1986 the editors were all Italian, but after 1986 scientists from other countries became editors of $B V$. In 1975, at the IAVCEI General Assembly in Grenoble, France, it was decided that the processes by which $B V$ was produced needed to be more rigorous, so a more inclusive international peer review process for research papers was established, with Volume 39 in 1976, edited by Franco Barberi and F. Esu Cugusi, being the first output under this new regime. It is unclear how the reviewing of papers prior to this was undertaken, but it was presumably largely done by the editor. Dissatisfaction amongst the IAVCEI community with the slowness of reviewing and processing of papers and publication of research papers came to a head in the mid-1980s, and a decision was made to transfer publication of $B V$ to Springer in Germany, coinciding with the appointment of the first non-Italian editor of $B V$, HansUlrich Schmincke, who was also the secretary-general at the time and was instrumental in the change in direction.

In $1986 B V$ was renamed Bulletin of Volcanology, was redesigned, took on a new look with the release of Volume 48 and has been continuously produced as a high-quality international journal since. From time to time its format has been revised and refreshed by each new editor. $B V$ is now one of the two mainstream international volcanological journals, the other being the Journal of Volcanology and Geothermal Research (published by the independent, commercial science publisher Elsevier), which was initiated in the 1970s as a result of dissatisfaction in the international volcanological community with the processes and timescales associated with $B V$ at the time. Other journals with a focus on volcanology have also emerged more recently (e.g. the the Journal of Applied Volcanology and Frontiers in Earth Sciences).

\subsection{Editors of Bulletin volcanologique and Bulletin of Volcanology}

These are the unsung heroes of IAVCEI. Their efforts, as volunteers, in managing the publication of research by the volcanological community on behalf of IAVCEI have long been undervalued. Until this compilation, IAVCEI did not even have a consolidated record of the who editors of $B V$ were. The following were editors of $B V$ during its history:

- Alessandro Malladra (Italy; also SG; 1924-1936)

- Francesco Signore (Italy; also SG; 1936-1959)

- Francesco Penta (Italy; also SG; 1959-1966)

- F. Esu Cugusi (Italy) - G. Marinelli (Italy; 1967)

- F. Esu Cugusi (Italy) - (Italy; 1968-1975)

- Franco Barberi (Italy) - F. Esu Cugusi (Italy; 19761984) 
- Hans-Ulrich Schmincke (Germany; also SG) - Steve Sparks (UK; 1986-1989)

- Hans-Ulrich Schmincke (Germany; also SG) - Gail Mahood (USA; 1990-1992)

- Hans-Ulrich Schmincke (Germany; also SG; 19931995)

- Don Swanson (USA) - Chris Newhall (USA; 19961999)

- Tim Druitt (France) - Jean-François Lénat (France; 2000-2003)

- John Stix (Canada) - Jean-François Lénat (France; 2004)

- John Stix (Canada) - JR Clark (Canada; 2005-2010)

- James White (New Zealand) - Linda White (New Zealand; 2011-2016)

- Andrew Harris (France) - Frances van Wyk de Vries (France; 2017-date of publication).

In addition, the countless members of the editorial board and reviewers of $B V$ over the years are acknowledged with thanks.

\subsection{Publishers of Bulletin volcanologique and Bulletin of Volcanology and years}

Bulletin volcanologique was published by Francesco Giannini e Figli in Naples, Italy, from 1924-1984, encompassing volumes 1 to 47; the Bulletin of Volcanology has been published by Springer, in Berlin, Germany, from 1986 to present, accounting for volumes 48 to 80 .

\subsection{From hardback only to digital only}

From 1924 to $2013 B V$ was published in hard copy, and in the first part of the 21 st century, it was published in both a hard-copy and digital version. From 2013 it became available only in digital form online through the Springer $B V$ website or through institutional libraries.

\subsection{A snapshot of the changing face of Bulletin volcanologique and Bulletin of Volcanology}

$B V$ has been redesigned numerous times since it was first published in 1924. The following are just some of the incarnations of the cover (Fig. 2).

\section{Catalogue of the Active Volcanoes of the World and Bulletin of Volcanic Eruptions}

An initial aim of IAVCEI when it was first formed in 19191922 was to establish a record of all the known active volcanoes around the world (Gasparini and Johnson, 1995). However, little was done until 1947, when William Q. Kennedy (UK) and James E. Richey (UK) published a first attempt to catalogue and produce a map of the volcanoes of the world as a supplement in Volume 7 of Bulletin volcanologique (Kennedy and Richey, 1947). At the 1948 IAVCEI General Assembly in Oslo, Norway, it was decided to build on the database of the catalogue and map of the volcanoes of the world produced in 1947 by subdividing the world into 19 regions, with the aim of producing a catalogue for each, under the editorship of Neumann van Padang (Gasparini and Johnson, 1995). These were published through the IAV-Bulletin volcanologique bureau in Naples, Italy, and between 1951 and 1975, 22 volumes were produced.

\begin{tabular}{llc}
\hline Part & Region & Year \\
\hline 1 & Indonesia & 1951 \\
2 & Philippine Islands & 1953 \\
3 & Hawaiian Islands & 1955 \\
4 & Africa and the Red Sea & 1967 \\
5 & Melanesia & 1957 \\
6 & Central America & 1956 \\
7 & Kuril Islands & 1959 \\
8 & Kamchatka and continental Asia & 1959 \\
9 & United States & 1959 \\
10 & Antarctica & 1960 \\
11 & Japan, Taiwan and Mariana Is- & 1962 \\
& lands & \\
12 & Colombia, Ecuador and Peru & 1966 \\
13 & Kermadec Islands and Tonga & 1959 \\
& and Samoa & \\
14 & Archipélago de Colón, San Félix & 1962 \\
& Island and Juan Fernández Is- & \\
& lands & 1962 \\
15 & Chile & 1963 \\
16 & Arabia and Indian Ocean & 1964 \\
17 & Turkey and the Caucasus & 1964 \\
18 & Italy & 1962 \\
19 & Greece & 1975 \\
20 & New Zealand & 1967 \\
21 & Atlantic Ocean & 1966 \\
22 & West Indies & \\
\hline & &
\end{tabular}

Subsequently, the United States Geological Survey has produced a catalogue of historically active volcanoes of Alaska (Miller et al., 1998).

Up until 1975 all reports of volcanic activity were published by national museum of the Smithsonian Institute as a monthly bulletin, SEAN (Scientific Event Alert Network), 
and later as the monthly Bulletin of Global Volcanism Network. The Smithsonian Institution Museum for Natural Science has also produced three editions of their "Volcanoes of the World" series, edited by the following individuals:

- Tom Simkin, Lee Siebert, L. McClelland, D. Bridge, Chris Newhall and John Latter (1981)

- Tom Simkin, Lee Siebert and L. McClelland (1994)

- Lee Siebert, Tom Simkin and Paul Kimberly (2011).

These represent the periodic summaries of those monthly reports under the Global Volcanism Program. The information is summarised and organised as visible data archives online (https://volcano.si.edu, last access: 11 July 2018).

The Smithsonian Institution Museum of Natural History also now provides a constantly updated online catalogue of volcanoes of the world through their Global Volcanism Program (GVP; https://volcano.si.edu/) that can be searched. For each volcano, there is a record of eruptions, reports, a location map and images. The website also provides an up-todate list of current eruptions.

In 1961 the Volcanological Society of Japan undertook a programme to record annually the eruptions and locations for each year by collecting the data on eruptions from volcano observatories around the world. Their reports were appended to volumes of Bulletin volcanologique. At least 33 volumes were produced up to 1994.

In addition, the Smithsonian Institution GVP, in collaboration with the United States Geological Survey, Arizona State University, Portland State University and IAVCEI, releases a weekly email report (VOLCANO: SmithsonianUSGS Weekly Volcanic Activity Report) that summarises the activity level, eruption events and crisis management status for volcanoes worldwide that are currently active or in a state of unrest. This report is distributed through an email news service called Volcano Listserv, which was initiated by Arizona State University under the stewardship of Jonathan Fink in 1984. It continues to provide this service to the volcanological community through the collaboration of the organisations mentioned and also through disseminating information about meetings and news raised by members.

\section{IAVCEI newsletter}

In addition to Bulletin of Volcanology, IAVCEI has had a newsletter for several decades that was initially sent to members through the mail but is now released on the IAVCEI website every 3 to 4 months. IAVCEI News summarises past, current and future activities of IAVCEI, including conferences, workshops, and the activities of commissions. It also acts as a forum for raising issues affecting IAVCEI and its membership. The current editor of the IAVCEI News is Karoly Nemeth, from Massey University, New Zealand, who was instrumental in refreshing the newsletter when he became editor in 2011. Prior to this the newsletter was largely prepared by the secretaries-general and assistants.

\section{IAVCEI Research Commissions, working groups and task groups}

Research commissions are now an integral part of the fabric of all IUGG Associations. They consist of groups of scientists who have a common interest in a particular research theme or problem. IAVCEI has a large number of commissions, most of whom are active, organising their own workshops and symposia as parts of IAVCEI's major conferences as well as independently between IAVCEI's major conferences.

Prior to the advent of research commissions in 1979, IAVCEI had rigid sections from 1960 to 1967, covering the fields of active volcanoes, volcano-physics, physics and chemistry of magmas, and paleovolcanology (Gasparini and Johnson, 1995). In 1967, when IAV became IAVCEI, more flexible working groups on topical research themes were introduced to replace sections, and these were changed to commissions and task groups in 1979. According to Gasparini and Johnson (1995), the aim of commissions was to promote and coordinate scientific activity on large themes on a permanent basis, whereas task groups would focus "on temporary problems or on frontier areas of volcanological research" over a finite period (Gasparini and Johnson, 1995).

In recent decades, all commissions and working and/or task groups have had a finite life depending on their level of activity, especially the leadership of these groups. Working and/or task groups have addressed specific issues and then ceased to operate (e.g. 2013 to 2015 IAVCEI Task Group on Crisis Protocols, led by Guido Giordano - Italy), which produced guidelines on the responsibilities, roles and liabilities of scientists involved in volcanic event management. Some commissions have become defunct or been decommissioned or resurrected under new leadership after some time of inactivity, and so the nature and themes of commissions have changed. Unfortunately, IAVCEI has not kept records, but an attempt to record the commissions and their leaders in IAVCEI's past is being made and will be summarised when completed on the IAVCEI website and included in IAVCEI's centenary booklet to be released at the 2019 IUGG General Assembly in Montréal, Canada.

One of the first thematic areas of research or investigation (an informal commission or working group) undertaken by IAVCEI when it was first formed was one on submarine volcanism, focussing largely, but not exclusively, on activity in the Indonesian archipelago, then part of the Dutch East Indies. There were regular reports in Bulletin volcanologique in a specifically titled section on submarine volcanic activity listed in the contents of the first volumes. 


\section{Collaboration with other IUGG associations}

In addition to collaborating in the organisation of interassociation symposia at each IUGG general assembly, IAVCEI also contributes to activities of the following IUGG Union Commissions:

- Climatic and Environmental Change (CCEC)

- Mathematical Geophysics (CMG)

- Geophysical Risk and Sustainability (GRC)

- Study of the Earth's Deep Interior (SEDI)

- Data and Information (UCDI)

- Planetary Sciences (UCPS).

In addition, it contributes to the activities of the following inter-association commissions:

- Joint Tsunami Commission

- International Heat Flow Commission

- Commission on Physics and Chemistry of Earth Materials

- Commission on Volcano Seismology and Acoustics

- Working Group on Electromagnetic Studies of Earthquake and Volcanoes (EMSEV)

- Commission on Volcano-Ice Interaction.

\section{Early career researcher network}

In 2013 IAVCEI instigated an early career research network to cater to the needs of postgraduate students, postdoctoral researchers and early career academics in establishing contacts and networks of like minds early in their careers. By engaging with the Early Career Researcher (ECR) Group and giving them a visible status in IAVCEI, the executive committee of IAVCEI wanted to establish a communication link with ECRs to help them develop a better understanding of how engaging in IAVCEI conferences and workshops would be beneficial to their careers. A successful scoping workshop was held at the 2013 Kagoshima IAVCEI General Assembly in Japan, together with another at the 2015 Prague General Assembly in the Czech Republic, followed by an evening ECR dinner to which a number of older scientists were invited as mentors. In 2018, the ECR Network Group has been invited to develop a new logo for IAVCEI, and ECR events are being planned for the 2019 Montreal Centenary General Assembly. The prime movers to help instigate the IAVCEI ECR network were Charlotte Vie (UK) and Sam Poppe (Belgium).

\section{IAVCEI awards}

In the latter half of its history IAVCEI introduced several awards to recognise outstanding scholarly and professional achievements.

\subsection{Wager Medal}

The first IAVCEI award, introduced in 1975, was for excellence in research. It was named the Wager Medal after Lawrence Rickard Wager (1904-1965), a petrologist at Oxford University, most famous for his seminal research on the petrological architecture and origins of the massive Skaergaard layered intrusive complex in Greenland. Although originally awarded every 4 years through a collaboration with the Royal Society of London, "the medal is (now) given every two years (i.e. at both Scientific and General Assemblies), to a scientist up to 15 years after Ph.D acquisition, who has made outstanding contributions to volcanology, particularly in the 8-year period prior to the Award" (IAVCEI website). Multiple nominations are usually received in each round. A list of past awardees can be found at the IAVCEI web page: https://www.iavceivolcano.org/ iavcei-awards/wager-medal.html (last access: 11 July 2018).

\subsection{Thorarinsson Medal}

In 1987 IAVCEI introduced the Thorarinsson Medal sponsored by the Geological Society of Iceland. Named after the famous Icelandic volcanologist Sigurdur Thorarinsson (1912-1983), the award is made "every four years at the IAVCEI Scientific Assembly to a scientist of outstanding distinction who has made fundamental contributions to research in volcanology" (IAVCEI website). A list of past awardees can be found at the IAVCEI web page: https://www. iavceivolcano.org/iavcei-awards/thorarinsson-medal.html (last access: 11 July 2018).

\subsection{Krafft Medal}

The Krafft Medal, introduced in 2004, is named after the French husband-and-wife team Maurice and Katia Krafft, who were tragically killed by a block and ash flow during an eruption of Mount Unzen in Japan in 1991, together with another volcanologist, Harry Glicken, and 40 people from the media. The medal is sponsored through a trust fund established by the Krafft family and "is awarded every 4 years at the IAVCEI Scientific Assembly to an individual who has made outstanding contributions to volcanology through service to the scientific community or to communities threatened by volcanic activity. The Krafft Medal honours those who have shown altruism and dedication to the humanitarian and applied sides of volcanology and those who have made selfless contributions to the volcanological community" (IAVCEI website). A list of past awardees can be found 
at the IAVCEI web page: https://www.iavceivolcano.org/ iavcei-awards/krafft-medal.html (last access: 11 July 2018).

\subsection{George Walker Award}

This award honours George P. L. Walker, originally from the UK, whose largely field-based research modernised and pioneered a quantitative approach to understanding volcanic eruptions, especially explosive eruptions. The award was introduced in 2004 and "is given every two years to a scientist up to 7 years after Ph.D acquisition. The award recognises achievements of a recent outstanding graduate in the fields of research encompassed by IAVCEI, or also a recent graduate whose achievements in volcanology involved operating in difficult circumstances" (IAVCEI website, 2018). The award is sponsored from a trust fund established by the Walker family. A list of past awardees can be found at the IAVCEI web page: https://www.iavceivolcano. org/iavcei-awards/george-walker-medal.html (last access: 11 July 2018)

\subsection{The Fisher Medal}

The Fisher Medal is in honour of Richard V. Fisher (19282002), who made major contributions to understanding the behaviour of pyroclastic density currents, based largely on field studies of their deposits: "The medal is given every 4 years at the IAVCEI Scientific Assembly to a scientist who has made outstanding contributions to volcanology based primarily upon field observations" (IAVCEI website). The medal was introduced in 2017. More information can be found at https://www.iavceivolcano.org/iavcei-awards/ fisher-medal.html (last access: 11 July 2018).

\subsection{Volcanic Surveillance and Crisis Management Award}

The Volcanic Surveillance and Crisis Management Award honours the personnel from institutions or organisations responsible for monitoring volcanoes (volcano observatories and/or other institutions) that have made a remarkable contribution to the mitigation of volcanic hazards and volcanic risks. Volcano monitoring, eruption forecasting and the mitigation of volcanic hazards are key objectives of volcanologists and a duty of volcano observatories worldwide. Criteria for eligibility include the following: successful hazard assessment and mitigation efforts, effective volcano surveillance and eruption forecasting, and/or effective crisis management: "This award will be presented every 2 years at the Cities on Volcanoes Meeting (CoVs)" (IAVCEI website). The first award was given in 2018 (https://www.iavceivolcano.org/iavcei-awards/ volcano-surveillance-and-crisis-management-award.html (last access: 11 July 2018)).

\section{IAVCEI Decade Volcanoes programme}

The United Nations declared 1990-2000 to be the International Decade for Natural Disaster Reduction. IAVCEI identified 16 volcanoes worldwide to be the focus of studies for the IAVCEI Decade Volcanoes programme (https://en.wikipedia.org/wiki/Decade_Volcanoes (last access: 11 July 2018)). The criteria for choosing these volcanoes included relatively recent eruptive activity, multiple potential hazards, proximity to centres of population, high risk levels to the population in the event of eruptions, reasonable access for study, and support from local scientific and government instrumentalities. IAVCEI had hoped that funding would be made available from the United Nations, but this did not eventuate. Most studies were funded by national research organisations and through international collaborative aid programmes. Not surprisingly some volcanoes received greater attention than others, depending on resources available. The 16 Decade Volcanoes selected were the following.

\begin{tabular}{lll}
\hline Volcano & Region & Country \\
\hline $\begin{array}{l}\text { Avachinsky }- \\
\text { Koryaksky }\end{array}$ & Kamchatka & Russia \\
Colima & Jalisco & Mexico \\
Galeras & Nariño & Colombia \\
Mauna Loa & Hawaii & United States \\
Mount Etna & Sicily & Italy \\
Mount Merapi & Central Java & Indonesia \\
Mount & North Kivu & Democratic \\
Nyiragongo & & Republic of \\
& & the Congo \\
Mount Rainier & Washington & United States \\
Mount & Campania & Italy \\
Vesuvius & & \\
Mount Unzen & Nagasaki - & Japan \\
& Kumamoto & \\
Sakurajima & Kagoshima & Japan \\
Santa María & Quetzaltenango & Guatemala \\
Santorini & South Aegean & Greece \\
Taal Volcano & Calabarzon & Philippines \\
Teide & Canary Islands & Spain \\
Ulawun & East New & Papua New \\
& Britain - West & Guinea \\
& New Britain & \\
& &
\end{tabular}

A number of these volcanoes have been volcanically active since being declared Decade Volcanoes, including Avachinsky (1991, 2002; Smithsonian Institute Global Volcanism Program - SI GVP - website, 2018); the Koryaksky volcano (2009; SI GVP); Colima (many times); Galeras in 1993, when six scientists (during Decade Volcanoes workshop) and two tourists were killed; Etna (many times); and Merapi (many times). The Nyiragongo volcano in the Congo had erupted catastrophically in 1977, involving extremely fast- 
flowing lava that killed 70 people. It experienced another eruption in 1994, during the civil war there, and then another large eruption in 2002, which again produced far-flowing lavas that inundated Goma and killed $\sim 150$ people due to $\mathrm{CO}_{2}$ asphyxiation and collapsed buildings. Mount Unzen underwent a 4-year-long eruption from 1991-1995 (see above), and Sakurajima has been almost constantly active, marked by frequent, spaced vulcanian explosions. The Santa María volcano has also been frequently active, and both Santorini and Teide have experienced seismic crises without an eruption occurring. The Ulawun volcano is frequently active and is notable for its very high emissions of $\mathrm{SO}_{2}$.

Data availability. The data that is presented in this paper and in the supplementary file have been sourced from the cited references, as well as from non-cited, generic sources (i.e. without specific authors identifiable) that are not available in digital form and therefore do not have accessible URLs. In particular, the following sources were used to identify, where possible, the names and years of service of past IAVCEI presidents, secretaries-general, committee members, and editors of Bulletin volcanologique $(B v)$ and $B u l$ letin of Volcanology $(B V)$.

The names of IAVCEI presidents and secretaries-general are listed on the IAVCEI website (https://www.iavceivolcano.org/, last access; 11 July 2018). Finding information about IAVCEI committee members and editors of $B v$ and $B V$ was more difficult. Sourcing information about these from $B v$ and $B V$ required accessing old hard copies of the journals from 1924 to 1986 because the digitised copies of these journals available on the $B V$ website do not contain scanned copies of the original hard covers of the journal issues on which the names of the editors of $B v$ and $B V$, and sometimes the IAVCEI president and secretary-general and committee members, are listed. In addition to accessing old hard copies of $B v$ and $B V$, copies of the IUGG Yearbook from 2004-2018 were used. These were formerly available in digital form online on the IUGG website but are no longer available there. In addition, IUGG Chronicles (1975, p. 313-315; 1976, p. 461-463; 1978, p. 216-218; 1980, p. $295-297 ; 1983$, p. $50-52 ; 1989$, p. $138-241 ; 1992$, p. $238-240$; 1995, p. 68-72, 298-299) and IUGG Comptes Rendus (1968, p. 206-208; 1975, p. 313-315) were also used.

Information about the IAVCEI Decade Volcanoes research initiative was sourced using: Wikimedia Commons Decade Volcanoes: https://upload.wikimedia.org/wikipedia/commons/4/42/ WikiReader_Decade_Volcanoes (last access: 11 July 2018). pdf and Wikipedia Decade Volcanoes: https://en.wikipedia.org/wiki/ Decade_Volcanoes (last access: 11 July 2018). Information about each Decade volcano is available on the website of the Smithsonian Institution Global Volcanism Program: https://volcano.si.edu/ (last access: 11 July 2018).

Supplement. The supplement related to this article is available online at: https://doi.org/10.5194/hgss-10-181-2019-supplement.

Author contributions. Raymond A. F. Cas was president of IAVCEI from 2011-2015 and is currently a member of the executive committee of IAVCEI, 2015-2019. He is an emeritus professor at Monash University in Melbourne, Australia, and an honorary adjunct professor at the University of Tasmania in Hobart, Australia. This work is his, and all sources of information have been cited and acknowledged.

Competing interests. The author declares that there is no conflict of interest.

Special issue statement. This article is part of the special issue "The International Union of Geodesy and Geophysics: from different spheres to a common globe" (https://www.hist-geo-space-sci. net/special_issue996.html). It is not associated with a conference.

Acknowledgements. Many people have helped in finding and providing information used in this overview. In particular, regarding information on membership of past executive committees, I thank Franz Kuglitsch, and for help in documenting the editors of Bulletin volcanologique and the Bulletin of Volcanology and their terms, Tim Druitt, Hans-Ulrich Schmincke, John Stix, Roberto Sulpizio, Mari Sumita and James White are thanked. Alik Ismail-Zadeh, Jo-Ann Joselyn, Steve McNutt, Joan Marti and an anonymous reviewer provided helpful comments on earlier versions of the paper, which improved it.

Edited by: Alik Ismail-Zadeh

Reviewed by: Setsuya Nakada, Joan Marti, and Steve McNutt

\section{References}

Gasparini, P. and Johnson, R. W.: History of IAVCEI, in: IUGG Chronicle, edited by: Melchior, P., 226, 68-72, 1995.

IAVCEI website: https://www.iavceivolcano.org/, last access: 11 July 2018.

Ismail-Zadeh, A.: Geoscience international: the role of scientific unions, Hist. Geo Space Sci., 7, 103-123, https://doi.org/10.5194/hgss-7-103-2016, 2016.

Kennedy, W. Q. and Richey, J. E.: Catalogue of the Active Volcanoes of the World, Supplement in Bulletin Volcanologique, vol. $7,1947$.

Lyons, H. G.: The Brussels meeting of the International Research Council, Nature, 103, 464-466, 1919.

Miller, T. P., McGimsey, R. G., Richter, D. H., Riehle, J. R., Nye, C. J., Yount, M. E., and Dumoulin, J. A.: Catalog of the historically active volcanoes of Alaska, US Geological Survey Open-File Report, 98, 104 pp., 1998.

Siebert, L., Simkin, T., and Kimberly, P.: Volcanoes of the world, Smithsonian Institution Museum of Natural Sciences, University of California Press, 2011.

Simkin, T., Siebert, L., McClelland, L., Bridge, R. D., Newhall, C., and Latter, J.: Volcanoes of the world. Smithsonian Institution Museum of Natural Sciences, University of California Press, 1981. 
Simkin, T., Siebert, L., and McClelland, L.: Volcanoes of the world. Smithsonian Institution Museum of Natural Sciences, University of California, 1994.
Smithsonian Institution: Global Volcanism Program, http://volcano. si.edu/, last access: 11 July 2018. 